\title{
Mechanistic study of chlordecone-induced endocrine disruption: Based on an adverse outcome pathway network
}

\author{
Lihua Yang a , Bingsheng Zhou ${ }^{\mathrm{a}}$, Jinmiao Zha ${ }^{\mathrm{b}, \mathrm{c},{ }^{*}, \text { Zijian Wang }}{ }^{\mathrm{d}}$ \\ a State Key Laboratory of Freshwater Ecology and Biotechnology, Institute of Hydrobiology, Chinese Academy of Sciences, Wuhan, 430072, China \\ b State Key Laboratory of Drinking Water Science and Technology, Research Center for Eco-Environmental Sciences, Chinese Academy of Sciences, Beijing, \\ 100085, China \\ c Beijing Key Laboratory of Industrial Wastewater Treatment and Reuse, Research Center for Eco-Environmental Sciences, Chinese Academy of Sciences, \\ Beijing, 100085, China \\ d State Key Laboratory of Environmental Aquatic Chemistry, Research Center for Eco-Environmental Sciences, Chinese Academy of Sciences, P.O. Box 2871, \\ Beijing, 100085, China
}

\section{H I G H L I G H T S}

- An adverse outcome pathway network was used to help reveal toxicity mechanism.

- Molecular docking was adopted to find possible molecular initiating event (MIE).

- Chlordecone acts as agonist of ERs and CYP19A in rare minnow.

- The results also pointed to other potential but important MIEs.

\section{A R T I C L E I N F O}

\section{Article history:}

Received 20 April 2016

Received in revised form

3 July 2016

Accepted 11 July 2016

Available online 20 July 2016

Handling Editor: David Volz

\section{Keywords:}

Chlordecone

Chinese rare minnow (Gobiocypris rarus)

Endocrine disruption

Adverse outcome pathway (AOP)

\begin{abstract}
A B S T R A C T
The adverse outcome pathway (AOP) framework could be helpful for chemical risk assessment and mechanistic research. The aim of the present study was to unravel the mechanism of chlordeconeinduced endocrine disruption by illustrating the main molecular initiating event (MIE)/perturbations responsible for the observed effects. In silico simulations were performed to predict the MIE(s), and the results pointed to agonistic interaction with estrogen receptors (ER $\alpha, E R \beta)$, androgen receptor (AR), cytochrome P450 (CYP19A) by chlordecone. In vivo endocrine disruptions were evaluated in rare minnow (Gobiocypris rarus) exposed to $0.01,0.1,1$ and $10 \mu \mathrm{g} \mathrm{L} \mathrm{L}^{-1}$ chlordecone from $2 \mathrm{~h}$ post-fertilization until sexually mature. In the females, increases of vitellogenin ( $v t g)$ mRNA levels in liver and gonad, plasma estradiol (E2), testosterone (T) and E2/T, and renalsomatic index confirmed the role of agonism of ER and CYP19A as MIEs, but the decreased gonadosomatic index, degenerated ovaries as well as the feedforward response pointed to other potential but important MIEs and corresponding AOPs. In the males, increased E2/T ratio, increased testis vtg mRNA levels and occurrence of intersex confirmed the roles of agonism of ER $\alpha$ and CYP19A as main MIEs in chlordecone-induced endocrine disruptions. Our results also fetches out the limit of AOPs in predicting the adverse outcomes and explaining the mechanism of chemicals at present, thus reflected a critical need for expanding AOPs and AOP network before using it in chemical risk assessment.
\end{abstract}

๑) 2016 Published by Elsevier Ltd.
Abbreviations: AOP, Adverse Outcome Pathway; MIE, Molecular Initiating Event; KE, Key Event; AO, Adverse Outcome; T, Testosterone; E2, Estradiol; ER, Estrogen Receptor; AR, Androgen Receptor; VTG, Vitellogenin; CYP, Cytochrome P450; GSI, Gonadosomatic Index; RSI, Renalsomatic Index; GnRH, Gonadotropin-releasing hormones; DMRT1, Doublesex and mab-3 related transcription factor 1.

* Corresponding author. State Key Laboratory of Drinking Water Science and Technology, Research Center for Eco-Environmental Sciences, Chinese Academy of Sciences, P.O. Box 2871, Shuangqing Rd 18, Haidian District, Beijing, 100085, PR China.

E-mail addresses: jinmiaozha@gmail.com, jmzha@rcees.ac.cn (J. Zha).

\section{Introduction}

In the past decade, defining and/or understanding toxicity pathways of chemicals has been the focus of many studies, and the comprehensive understanding of information from such studies has become a key step toward the development of a new generation of predictive toxicology tools. Recently, the adverse outcome pathway (AOP) has been advocated for chemical risk assessment and mechanistic study (Ankley et al., 2010; Groh et al., 2015; Zhou, 2015). This approach presents a detailed progression of a series of 
key events (KE) following a molecular initiating event (MIE) leading to an adverse outcome (AO) within a logical framework (Knapen et al., 2015), thus facilitate greater understanding at theoretic level. Since a single AOP may not capture all events contributing to any relevant toxic effect, AOP networks are therefore required to present more realistically potential effects and to reveal previously unknown links between biological pathways (Knapen et al., 2015). However, there is still considerable work needed to demonstrate and maximize the utility of this framework. In the near future, comprehensive understanding of the toxicological mechanism was needed to help put the empirical support in context and/or help support and expand AOP network.

In this regard, chlordecone may provide good example for probing the utility and limits of the current AOPs. Chlordecone, also named kepone, was intensively used as an organochlorine insecticide to fight against banana root borer, apple scab and powdery mildew, tobacco wireworms as well as slugs, snails, and fire ants (NLM, 2004). Although banned since 1978 in the United States of America (IARC, 1979), chlordecone still could be detected in rivers (up to $4 \mu \mathrm{g} \mathrm{L}^{-1}$ ), wild fish (up to $0.42 \mu \mathrm{g} \mathrm{g}^{-1}$ ) and human $\left(0.41 \mu \mathrm{g} \mathrm{L}^{-1}\right.$ in cord blood) worldwide due to its high lipophilicity and resistance to degradation (Luellen et al., 2006; Guldner et al., 2010; Boucher et al., 2013). The UNEP (2007) have listed chlordecone into the Stockholm Convention on Persistent Organic Pollutants to call for specific concerns on its potential pollution and risk to wild animals as well as humans.

Observed chlordecone-induced reproductive effects include oligospermia, reduced sperm motility, and decreased libido in occupationally exposed men (Faroon et al., 1995). Similar results including testicular atrophy, altered sperm characteristics, persistent vaginal estrus, and anovulation were observed in chlordeconetreated laboratory animals (U.S. EPA, 1986). Degenerative changes including reduced growth of oocytes and appearance of atretic follicles were also reported in fish treated with chlordecone (Srivastava and Srivastava, 1994). These observations mimic similar effects produced by excessive estrogen (Scippo et al., 2004), and chlordecone has been proved to act as a competitive agonist in vitroly for both subtypes of estrogen receptors (ER $\alpha$ and $\beta$ ) (Kuiper et al., 1998). Besides, the database of Pubchem Bioassay (NIH, 2016), which mainly uses cell-based and biochemical in vitro tests, also provided evidence for agonistic and/or antagonistic activity of androgen receptor (AR) and Cytochrome P450 19A (CYP19A) by chlordecone. The agonism and/or antagonism of steroid receptors and CYP19A as MIE may lead to different series of KEs, some of which could be contrary as indicated by the already described AOPs (Knapen et al., 2015). Hence it is interesting to figure out the prospective MIE and unravel the process driving the observed effects upon chlordecone exposure. The definition of key MIE within the integrated strategy of AOP characterisation may be another challenge for the extension of this paradigm. In silico approaches such as molecular docking could provide clear view of the interactions between xenobiotic chemicals and biomolecules, therefore represent reasonable tools for predicting the potential MIE(s) of test chemicals.

Above all, the main purpose of this study is to predict the potential MIE of chlordecone by molecular docking, to evaluate the endocrine disrupting capabilities using rare minnow as an in vivo model fish, and to unravel the main MIE(s)/perturbations responsible for the observed effects.

\section{Materials and methods}

\subsection{Chemicals}

Chlordecone (purity > 99.5\%) was purchased from Supelco
Chemical Co. (St. Louis, MO, USA), and high-performance liquid chromatography-grade acetone was purchased from Sigma Chemical Co. (St. Louis, MO, USA). Methanesulfonate (MS-222) were purchased from Sigma-Aldrich (Fluka, Shanghai, China).

\subsection{Test fish and culture conditions}

The rare minnow has been maintained in the laboratory of Aquatic Ecotoxicology in Research Center for Eco-Environmental Sciences, Chinese Academy of Sciences, for more than 10 years. The brood stock was kept in a flow-through system filled with dechlorinated tap water $(\mathrm{pH} 7.2-7.6$; hardness $44.0-61.0 \mathrm{mg}$ $\mathrm{CaCO}_{3} \mathrm{~L}^{-1}$ ) and subjected to a 16:8 h light:dark cycle at $25 \pm 1^{\circ} \mathrm{C}$. The brood stock was fed newly hatched brine shrimp (Artemia nauplii) twice and granule food (TetraMin, Tetra Werke, Melle, Germany) once daily. Wastes and residues were removed daily, and the test equipment and chambers were cleaned once a week.

\subsection{Experimental design}

Embryos from one male-female pair with relatively stable spawning period, egg laying amount and fertility rate were used for experiments. Embryos that developed normally and reached the blastula stage ( $2 \mathrm{~h}$ post-fertilization, hpf) were equally divided into 6 groups and radomly distributed into 6 glass beakers $(n=80-100$ each, depending on the total number of embryos) containing $200 \mathrm{~mL}$ exposure solution (water control, solvent control, or 0.01, $0.1,1,10 \mu \mathrm{g} \mathrm{L}^{-1}$ chlordecone, respectively). The exposure concentrations included environmental levels and the upper limit concentration showed no lethality in the $96 \mathrm{~h}$ acute test using larval rare minnow ( 7 days post fertilization, dpf). Such experiments were repeated for 10 times, in other words, there were ten beakers for each experimental and control group. At $14 \mathrm{dpf}$ the larvae were transferred into a flow-through system and exposed to corresponding concentrations of chlordecone as previously described (Yang et al., 2010). Specifically, for each concentration group 100 larvae were radomly selected from ten beakers ( 10 from each), and assigned into 2 18-L glass tanks (50 each). There were 2 tanks for each group because of the limit of spaces and tanks. The remaining larvae were sampled for other analysis. Final concentrations of acetone in all treatments throughout the exposure experiment were lower than $1: 100,000$ ( $\mathrm{vol} / \mathrm{vol})$. Although the water bone concentrations of chlordecone were not determined in the present study, we supposed that the actual concentrations were close to nominal concentrations based on the following reasons: First, chlordecone has been proved to be highly stable in water; second, the rates of stock solutions and dechlorinated tap water were strictly controlled in the flow-through system and adjusted every day which ensured the retention time shorter than $4 \mathrm{~h}$ or the renew times more than 6 in a day; third, according to earlier studies in our laboratory, the deviation of the concentrations could be controlled within $\pm 15 \%$ (Yang et al., 2011).

As documented previously, rare minnow could be sexually matured at 4 month (Wang, 1992). During the flow-through exposure, the development of gonad (from 2 to 3 fish) were examined every two weeks since 3 month post hatch by observing the gonad after dissection. Therefore, after about 5 month post hatch, fish were considered sexually matured and sacrificed after anesthetized with $0.01 \%$ MS-222. For each fish, body length and weight were quickly determined, and blood was collected in heparinized microcapillary tubes. The samples were immediately centrifuged $\left(8000 \times \mathrm{g}, 10 \mathrm{~min}, 4^{\circ} \mathrm{C}\right)$, and plasma was collected and kept frozen at $-80{ }^{\circ} \mathrm{C}$ until use. The abdomen of each fish was dissected, then liver, gonad and brain were carefully isolated and weighed. Three liver (or brain or gonad) of female or male fish from 
each tank were collected as one replicate for real-time polymerase chain reaction (RT-PCR) analysis, and there were two experimental replicates for each sample. The samples were flash frozen in liquid nitrogen and then stored at $-80^{\circ} \mathrm{C}$ until analysis. Gonad (or kidney) from four males and four females in each group ( 2 males and 2 females from each tank) were fixed in Bouin's solution (71\% saturated picric acid, $24 \%$ formaldehyde, $5 \%$ glacial acetic acid; SigmaAldrich, USA) for histopathological examination.

\subsection{Tissue-somatic indices}

The tissue-somatic indices of rare minnow was calculated as follow:

$$
\begin{aligned}
& \text { GSI = gonad weight }(\mathrm{g}) / \text { body weight }(\mathrm{g}) \times 100 \\
& \text { RSI = kidney weight }(\mathrm{g}) / \text { body weight }(\mathrm{g}) \times 100
\end{aligned}
$$

\subsection{Histopathology}

After 24 h gonad (or kidney) samples fixed in Bouin's solution were transferred to $70 \%$ ethanol and processed routinely according to standard histological methods and embedded in paraffin wax as described by Wolf et al. (2004). The left and right slides of gonad (or kieney) from each fish were horizontally cut to sections at 3-4 $\mu \mathrm{m}$ and stained with hematoxylin and eosin, and the section of the paraffin blocks were analyzed on an Axioskop 2 mot plus optical microscope (Zeiss, Germany) and digitized with an AxioCam digital camera (Zeiss) using the Application Suite software AxioVision Rel. 4.5 (Zeiss).

For testis sections, two digital images using the $10 \times$ microscope objective and two using the $40 \times$ microscope objective were obtained (i.e., 4 images per fish and 16 images total per treatment). For ovarian sections, four digital images using the $10 \times$ microscope objective were obtained (i.e., 4 images per fish and 16 images total per treatment). For each digital images of ovarian sections, ovarian follicles were manually tagged with different cell types including previtellogenic oocytes (PO), early vitellogenic oocytes (EVO), vitellogenic oocytes (VO), and atresia. Tagging was performed by a single pathologist to avoid inconsistencies.

\subsection{Plasma sex hormones}

Plasma sex hormones were measured using the enzyme-linked immunosorbent assay (ELISA) kits (Shanghai Hufeng Chemical Industry Co., China) according to the manufacturer's instructions. The dilution curves of immunoreactive steroid hormones were parallel to the standard curves validating use of these kits for steroid hormones in rare minnow plasma. The assay sensitivity for estradiol (E2) and T were $1.5 \mathrm{pg} \mathrm{mL}^{-1}$ and $6 \mathrm{pg} \mathrm{mL}^{-1}$, respectively, and the intra-assay coefficients of variation were all $<10 \%$. All samples were analyzed simultaneously to avoid interassay variability.

\subsection{Relative quantification by real-time $P C R$}

Relative expression of gonadotropin-releasing hormones (gnrh3) and Cytochrome P450 19B (cyp19b) in the brain, er $\alpha, \operatorname{er} \beta$ and vitellogenin ( $v t g)$ in the liver and er $\alpha, e r \beta, v t g, a r$, Doublesex and mab-3 related transcription factor 1 (dmrt1), Cytochrome P450s (cyp11a, cyp17 and cyp19a) in the gonad were determined. Extraction, purification, and quantification of total RNA, first-strand cDNA synthesis, and real-time PCR were performed as described previously (Yang et al., 2010) in Mx3005P RT-PCR system
(Stratagene, USA) using Brilliant II SYBR Green QPCR master kits (Stratagene, USA). The cycling conditions used were: an initial denaturation step of $95^{\circ} \mathrm{C}$ for $10 \mathrm{~min}$, followed by 40 cycles of $95^{\circ} \mathrm{C}$ for $30 \mathrm{~s}, 57^{\circ} \mathrm{C}$ for $40 \mathrm{~s}$ and $72{ }^{\circ} \mathrm{C}$ for $30 \mathrm{~s}$, and the last cycle of $95^{\circ} \mathrm{C}$ for $30 \mathrm{~s}, 57^{\circ} \mathrm{C}$ for $30 \mathrm{~s}$ and $72{ }^{\circ} \mathrm{C}$ for $60 \mathrm{~s}$ for dissociation curve. All of the cDNA samples were analyzed in triplicates (technical replicates). Prior to the transcriptional assay, we assessed the transcriptional stability of commonly used reference genes such as $r p l 8$, $18 \mathrm{~s}$, gapdh, $\beta$-actin using geNorm analyses (http://medgen.ugent. be/genorm). The results indicated $\beta$-actin as the most stable gene under present experimental conditions and was chosen as an internal control. The mRNA expression was normalized for $\beta$-actin mRNA expression. The primer pairs used for real-time PCR were listed in Table S1.

\subsection{Molecular docking}

Molecular docking was performed and binding energies were calculated for all docked compounds using Discovery Studio 4.0 (Accelrys Software, San Diego, CA, USA). The three-dimensional (3D) structures of chlordecone were obtained from the PubChem Substance database (http://www.ncbi.nlm.nih.gov/pcsubstance) and optimized with the MMFF94 method. The crystal structure of $\mathrm{ER} \alpha$ (agonistic-1ERE; antagonistic-3ERT), ER $\beta$ (agonistic-2JJ3; antagonistic-1L2J), AR (agonistic-2AM9; antagonistic-1Z95), CYP11A1 (agonistic-3N9Y; antagonistic-3N9Z), CYP17A1 (agonistic-3RUK; antagonistic-3SWZ), CYP19A1 (agonistic-3S79; antagonistic-4GL5) were obtained from the RCSB protein data bank (http://www.pdb.org), and used for docking modeling after preparation. After active sites were defined, docking poses were generated using the Libdock module. During the simulation, docking preferences was set as high quality and conformation method was set as best. The steepest descent method was used for minimization. Other parameters were set as default values. The binding energies were obtained by calculate binding energies tools with default parameters. The conformation with the highest libdock score for each protein was selected as the most likely bioactive conformation.

\subsection{Statistical analysis}

All quantitative data are expressed as mean \pm S.E. Prior to oneway analysis of variance (ANOVA), data normality and homogeneity of variance were analyzed using the Kolmogorov-Smirnov and Levene's tests, respectively. If necessary, data were log-transformed to achieve approximate normality. Dunnett's test were used to compare data between treatments using SPSS (version 17.0). A probability of $p<0.05$ was considered to be statistically significant.

\section{Results}

\subsection{In silico simulate of interactions of chlordecone with key proteins}

No poses were generated for chlordecone with the antagonistic conformations of all proteins studied in the present study or for the agonistic conformations of CYP11A1 and CYP17A1. In contrast, chlordecone could be docked with the agonistic conformations of $\mathrm{ER} \alpha, \mathrm{ER} \beta, \mathrm{AR}$ and CYP19A1. The binding energy of complex for chlordecone with these proteins were $-36.70,-45.46,-40.39$ and $-70.55 \mathrm{kcal} \mathrm{mol}^{-1}$, respectively, indicating the highest affinity of chlordecone with agonistic CYP19A1.

The interacting modes of chlordecone and the docked proteins were further analyzed and are shown in Fig. 1. The binding of chlordecone with ER $\alpha$ (Fig. 1A) may be mainly attributed to van der 
Waals force (green disc) followed by electrostatic forces (purple disc) as well as hydrophobic force indicated by the solvent accessible surface area (SASA) (light blue). Besides, H-bond was found formed between the oxygen atom with the residues of HIS467 in ER $\beta$-chlordecone complex (Fig. 1B) and $\mathrm{Cl}$ atom with the residue of LYS473 in CYP19A1-chlordecone complex (Fig. 1D).

\subsection{In vivo effects on hypothalamic-pituitary-gonadal (HPG) axis in} rare minnow

\subsubsection{Tissue-somatic indices and plasma steroid hormones}

There were no statistical differences in GSI, RSI or plasma steroids between the solvent control (data not shown) and the water control, therefore water control was used as control for statistical analysis and was given in Table 1 . In the females, GSI were decreased at $10 \mu \mathrm{g} \mathrm{L}^{-1}(p<0.05)$, and RSI were increased at 1 and $10 \mu \mathrm{g} \mathrm{L}^{-1}(p<0.05)$. The tissue-somatic indices of male fish showed no obvious changes upon chlordecone exposure (Table 1). Plasma $\mathrm{E} 2$ and $\mathrm{T}$ levels in the females were significantly elevated at all concentrations. Maximum fold change was 34- and 14-fold for E2 and $\mathrm{T}$, respectively. For males, significant increases in plasma E2 were observed at concentrations greater than $0.01 \mu \mathrm{g} \mathrm{L}^{-1}$ (up tp 24fold). Plasma T was also significantly increased in males by 2.2 -fold at $0.01 \mu \mathrm{g} \mathrm{L}^{-1}$ and 1.6-fold at $1 \mu \mathrm{g} \mathrm{L}^{-1}$ (Table 1 ).

\subsubsection{Histopathology of gonad from rare minnow}

Histological inspection revealed the presence of developing oocyte including $\mathrm{PO}, \mathrm{EVO}$, and $\mathrm{VO}$ in ovaries from the controls (Fig. 2A). The number of $\mathrm{PO}$ increased and atresia were observed in ovaries from fish exposed to $10 \mu \mathrm{g} \mathrm{L}^{-1}$ chlordecone (Fig. 2B). The testis of control rare minnow displayed normal spermatozoa (SP) and different stages of spermatogenic cyst (SPC) (Fig. 2C). However, testicular oocytes were observed in one out of four fish at $10 \mu \mathrm{g} \mathrm{L}^{-1}$ chlordecone which presented abundance of PO and EVO at one
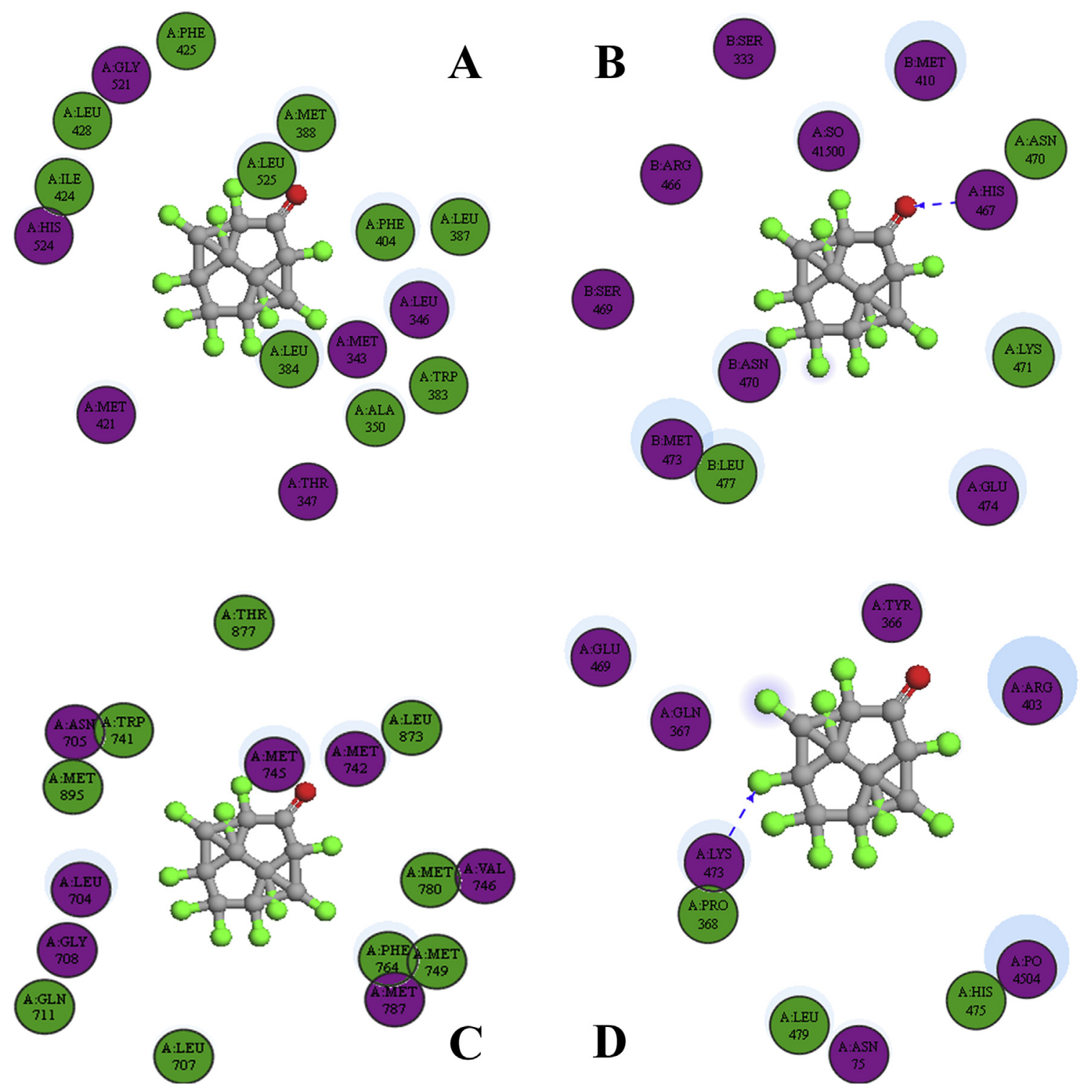

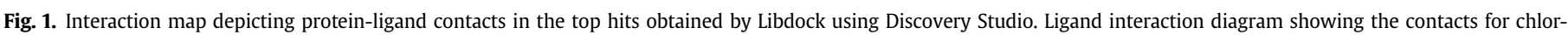

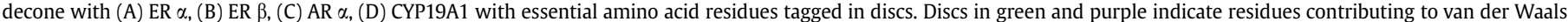

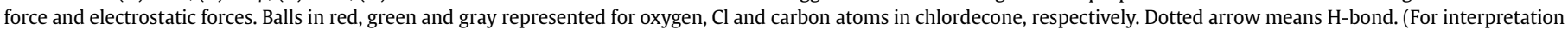
of the references to colour in this figure legend, the reader is referred to the web version of this article.) 
Table 1

Tissue-somatic indices and plasma steroid hormones of adult rare minnow.

\begin{tabular}{|c|c|c|c|c|c|c|}
\hline \multicolumn{2}{|c|}{ Concentration $\left(\mu \mathrm{g} \cdot \mathrm{L}^{-1}\right)$} & $\operatorname{GSI}(\%)(\mathrm{n}=12-18)$ & $\mathrm{RSI}(\%)(\mathrm{n}=12-18)$ & $\mathrm{E} 2\left(\mathrm{pg} \mathrm{mL}^{-1}\right)(\mathrm{n}=4)$ & $\mathrm{T}\left(\mathrm{pg} \mathrm{mL}^{-1}\right)(\mathrm{n}=4)$ & $\mathrm{E} 2 / \mathrm{T}(\mathrm{n}=4)$ \\
\hline Female & $\begin{array}{l}\text { Control } \\
0.01 \\
0.1 \\
1 \\
10\end{array}$ & $\begin{array}{l}9.83 \pm 4.68^{\mathrm{a}} \\
7.10 \pm 4.63^{\mathrm{a}} \\
8.18 \pm 4.83^{\mathrm{a}} \\
7.82 \pm 4.31^{\mathrm{a}} \\
4.49 \pm 2.64^{\mathrm{b}}\end{array}$ & $\begin{array}{l}0.35 \pm 0.15^{\mathrm{a}} \\
0.38 \pm 0.12^{\mathrm{a}} \\
0.39 \pm 0.18^{\mathrm{a}} \\
0.45 \pm 0.16^{\mathrm{b}} \\
0.45 \pm 0.13^{\mathrm{b}}\end{array}$ & $\begin{array}{l}13.3 \pm 1.2^{\mathrm{a}} \\
456 \pm 58^{\mathrm{c}} \\
563 \pm 78^{\mathrm{c}} \\
356 \pm 48^{\mathrm{b}} \\
279 \pm 17^{\mathrm{b}}\end{array}$ & $\begin{array}{l}11.2 \pm 1.7^{\mathrm{a}} \\
\text { N.D. } \\
159 \pm 27^{\mathrm{c}} \\
33.3 \pm 5.3^{\mathrm{b}} \\
69.0 \pm 9.0^{\mathrm{b}}\end{array}$ & $\begin{array}{l}1.19 \pm 0.19^{\mathrm{a}} \\
\text { N.D. } \\
3.54 \pm 1.74^{\mathrm{c}} \\
10.7 \pm 1.07^{\mathrm{c}} \\
4.04 \pm 0.76^{\mathrm{b}}\end{array}$ \\
\hline Male & $\begin{array}{l}\text { Control } \\
0.01 \\
0.1 \\
1 \\
10\end{array}$ & $\begin{array}{l}3.30 \pm 0.94 \\
2.53 \pm 1.71 \\
2.72 \pm 0.98 \\
4.74 \pm 1.85 \\
3.46 \pm 2.64\end{array}$ & $\begin{array}{l}0.34 \pm 0.14 \\
0.28 \pm 0.19 \\
0.26 \pm 0.08 \\
0.25 \pm 0.11 \\
0.29 \pm 0.14\end{array}$ & $\begin{array}{l}10.3 \pm 5.46^{\mathrm{a}} \\
123 \pm 18^{\mathrm{b}} \\
129 \pm 26^{\mathrm{b}} \\
246 \pm 26^{\mathrm{c}} \\
\text { N.D. }\end{array}$ & $\begin{array}{l}27.0 \pm 7.17^{\mathrm{a}} \\
59.6 \pm 5.8^{\mathrm{b}} \\
37.5 \pm 7.9 \mathrm{a}^{\mathrm{a}} \\
43.3 \pm 8.5^{\mathrm{b}} \\
19.4 \pm 6.8^{\mathrm{a}}\end{array}$ & $\begin{array}{l}0.38 \pm 0.09^{\mathrm{a}} \\
2.06 \pm 0.37^{\mathrm{b}} \\
3.44 \pm 0.68^{\mathrm{b}} \\
5.68 \pm 0.81^{\mathrm{c}} \\
\text { N.D. }\end{array}$ \\
\hline
\end{tabular}

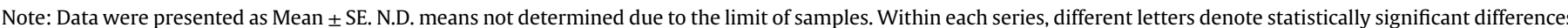
among groups (Dunnett's test; $p<0.05$ ).

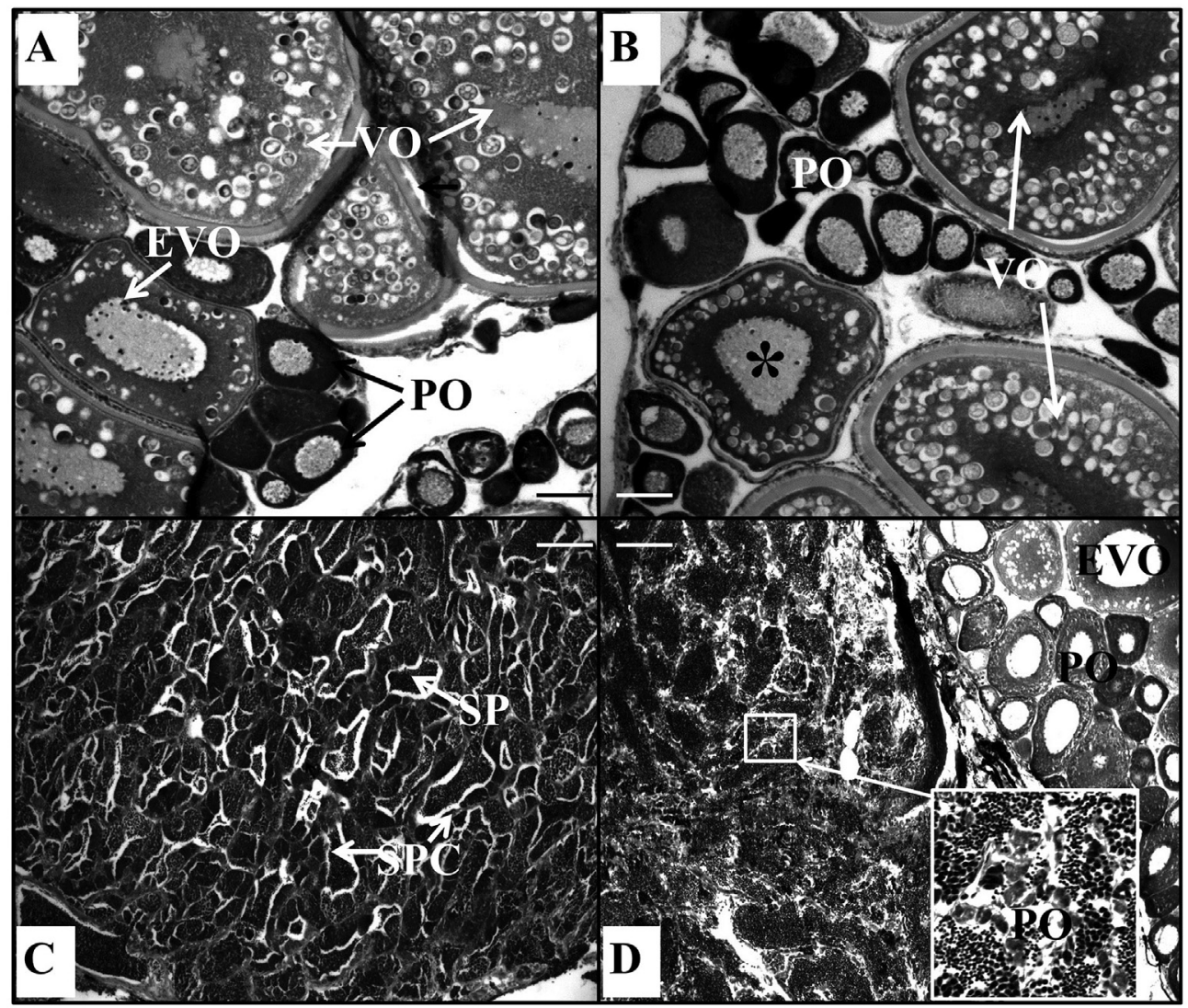

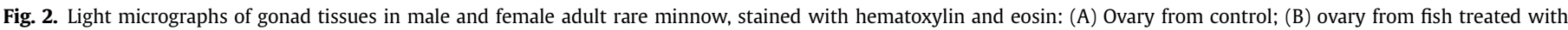

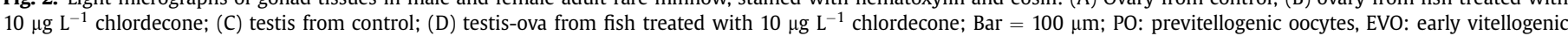
oocytes, VO: vitellogenic oocytes, *: atresia, SP: spermatozoa, SPC: spermatogenic cyst.

slide and developing SPC with a number of PO at the other slide (Fig. 2D). At $1 \mu \mathrm{g} \mathrm{L}^{-1}$ chlordecone, PO were also observed in the testis of one out of four fish. Testis from fish treated by 0.01 and $0.1 \mu \mathrm{g} \mathrm{L}^{-1}$ chlordecone showed similar developmental status with those from the control group.

Microphotographs of kidney (Fig. S1) also indicated histopathological changes such as excessively developed capillaries in glomerulus and necrosis of the tubular epithelia in female fish exposed to $10 \mu \mathrm{g} \mathrm{L}^{-1}$ chlordecone.

\subsubsection{Transcription of genes in HPG axis in adult rare minnow}

No statistical differences in mRNA levels of the detected genes were observed between the solvent control (data not shown) and the water control for both males and females.

In adult females, brain transcripts of gnrh 3 and cyp $19 b$ were significantly up-regulated at 0.1 and $1 \mu \mathrm{g} \mathrm{L}^{-1}$ by 11.3 -, 7.8-fold and 3.3-, 4.8-fold $(p<0.05)$, but not at 0.01 and $10 \mu \mathrm{g} \mathrm{L}^{-1}$, both showing inverted " $U$ " form dose-dependent relationships (Fig. 3A). While in the liver, mRNA levels of er $\alpha$, er $\beta$, vtg showed "U" form dosedependent relationships: the transcripts of er $\alpha$ were up-regulated at 0.01 and $10 \mu \mathrm{g} \mathrm{L}^{-1}$ by $2.1-, 5.8$-fold but down-regulated $45 \%$ and $65 \%$ at 0.1 and $1 \mu \mathrm{g} \mathrm{L}{ }^{-1}(p<0.05)$, respectively; and those of er $\beta$ and $v \operatorname{tg}$ were up-regulated at $0.01,0.1$ and $10 \mu \mathrm{g} \mathrm{L}^{-1}$ maximally by 7.4-fold, and at 0.01 and $10 \mu \mathrm{g} \mathrm{L}^{-1}$ maximally by 4.8 -fold $(p<0.05)$, respectively (Fig. 3A). In the ovary, long term exposure to chlordecone resulted in profound induction of genes related to 

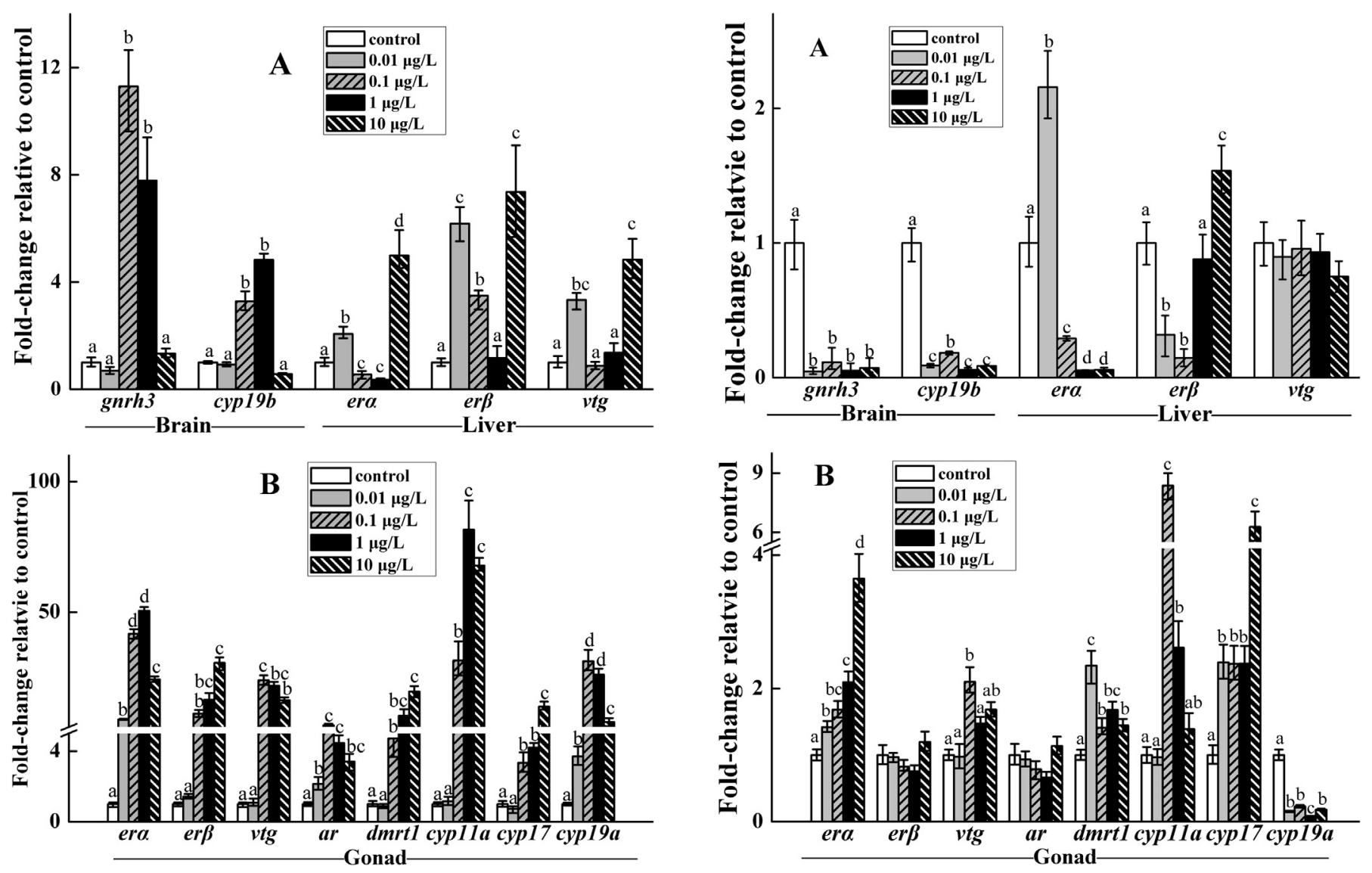

Fig. 3. The effects of chlordecone on transcripts of genes involved in the HPG axis in female rare minnow (Gobiocypris rarus) Mean \pm S.E. $(\mathrm{n}=6) .{ }^{*} p<0.05,{ }^{* *} p<0.01$.

Fig. 4. The effects of chlordecone on transcripts of genes involved in the HPG axis in male rare minnow (Gobiocypris rarus) Mean $\pm \mathrm{SE}(\mathrm{n}=6) .{ }^{*} p<0.05,{ }^{* *} p<0.01$.

reproduction (Fig. 3B): the transcripts of er $\alpha$, ar, and cyp19a were promoted at all treatments maximally by 50 -fold, 6.7 -fold, and 31 fold ( $p<0.05)$, respectively; and those of $\operatorname{er} \beta, v \operatorname{tg}, d m r t 1$, cyp11 $a$ and cyp17 were also up-regulated after exposure to chlordecone at and higher than $0.1 \mu \mathrm{g} \mathrm{L}^{-1}$ maximally by 31 -fold, 24-fold, 20-fold, 82fold and 14-fold ( $p<0.01)$, respectively.

For adult males, brain transcripts of gnrh3 and cyp19b were significantly down-regulated at all concentrations $\mu \mathrm{g} \mathrm{L}^{-1}$ by maximally by $96 \%$ and $94 \%$ ( $p<0.05$ ), respectively (Fig. $4 A$ ). In the liver, mRNA levels of er $\alpha$ were significantly increased at $0.01 \mu \mathrm{g} \mathrm{L}^{-1}$ but decreased at $0.1,1$ and $10 \mu \mathrm{g} \mathrm{L}^{-1}$ maximally by $94 \%(p<0.05)$; in contrast, those of er $\beta$ were significantly decreased at 0.01 and $0.1 \mu \mathrm{g} \mathrm{L}^{-1}$ by $68 \%$ and $85 \%$ but increased at $10 \mu \mathrm{g} \mathrm{L}^{-1}$ by 1.5 -fold $(p<0.05)$; however, there lacked significant changes of hepatic $v \operatorname{tg}$ mRNA levels (Fig. 4A). In the testis, the transcripts of er $\alpha$, dmrt1, cyp17 at all concentrations were up-regulated maximally by 3.6fold, 2.3-fold and 6.3-fold ( $p<0.05$ ), respectively; and those of $v \operatorname{tg}$ and cyp11 $a$ were also up-regulated at 0.1 and $1 \mu \mathrm{g} \mathrm{L}-1$ (8.7-, 2.6fold), and at all concentrations (2.4-, 2.4-, 2.4-, 6.3-fold). In contrast, significant reductions were observed in transcription cyp19a at all concentrations maximally by $92 \%$ ( $p<0.05$ ), respectively (Fig. 4B).

\section{Discussion}

The present study aimed to elucidate the underlying mechanism of chlordecone-induced endocrine disruptions by predicting the possible $\operatorname{MIE}(\mathrm{s})$ and comparing with the expected pattern of responses based on AOPs relevant to the predicted MIEs. The molecular docking results revealed multiple MIEs including agonistic interactions with $\mathrm{ER} \alpha, \mathrm{ER} \beta, \mathrm{AR}$ and aromatase. A profound endocrine disrupting activity was documented in rare minnow which were exposed to chlordecone from $2 \mathrm{hpf}$ until sexually mature. Agonism of ERs and CYP19A may play important role as MIEs in both male and female fish, but evoked feed-forward and feed-back responses of HPG axis, respectively. Our results also reflected the limitation of present knowledge of AOPs and AOP network, and further study would be needed to improve and maximize the utility of the AOP framework.

Within an AOP, one difficult but important step is to define the site of action, which can relate to biological effects at the local or systemic level and determine the nature of the adverse outcome. In the present study, molecular docking was used to predict the potential MIE(s) responsible for chlordecone-induced endocrine disruptions. In the context of known effects on endocrine system by chlordecone (Srivastava and Srivastava, 1994; Scippo et al., 2004; $\mathrm{NIH}, 2016$ ), the agonistic and antagonistic conformations of sex steroid receptors (ER $\alpha, E R \beta, A R)$ and Cytochrome P450 enzymes (CYP11A1, CYP17A1 and CYP19A1) were selected to evaluate their affinity with chlordecone. However, the results showed that chlordecone could only be docked with the agonistic conformations of ER $\alpha, E R \beta, A R$ and CYP19A1. Previous in vitro studies demonstrated that chlordecone exhibited relatively high affinity for recombinant human estrogen receptors (Scippo et al., 2004), and its affinities for both subtypes (ER $\alpha$ and $E R \beta$ ) were approximately equal (Kuiper et al., 1998). In the present study, the binding energies of complex for chlordecone and steroid receptors were approximate equivalent, while the CYP19A1-chlordecone complex may be more stable with a lower minus binding energy. 
Interestingly, we also noticed that the natural ligand of the active sites in the CYP19A1-chlordecone complex was $\mathrm{PO}_{4}$, indicating that the phosphorylation may be involved in the agonism of CYP19A by chlordecone. The phosphorylation of several curial residues has been demonstrated to regulate CYP19A activity (Balthazart et al., 2001) and could be induced by E2 (Fester et al., 2015). Therefore the agonism of ER $\alpha, E R \beta, A R$ and CYP19A1 could be possible MIEs for the endocrine disrupting outcomes evoked by chlordecone.

It is worth noting that AOPs are usually presented linearly, and AOP networks are required to describe most toxicologically relevant processes and to predict AOs in most real-world scenarios (Knapen et al., 2015). In this regard, the in vivo effects of chlordecone on the HPG axis of Chinese rare minnow were studied by determining a series of parameters at different levels as adverse outcomes and key events defined in the AOPs related to the predicted MIEs. The differential responses were separately discussed in males versus females to unravel the MIE(s)/perturbations driving the observed effects.

In the females, extremely high transcriptional levels of all genes determined were found in adult females following exposure to chlordecone. Natural estrogens (i.e. E2) as well as xenoestrogens (i.e. bisphenol A, BPA) can regulate the estrogen-responsive genes (i.e. $v t g$ ) by binding to ERs (Kurosawa et al., 2002; Bjornstrom and Sjoberg, 2005). VTG is considered primarily synthesized in liver, while recent studies have shown that vtg mRNA could also be detected in extrahepatic tissues, especially the gonad, and could be induced by E2 (Wang et al., 2005). In the present study, simultaneous elevation of $\operatorname{er} \alpha, \operatorname{er} \beta$ and elevated $v \operatorname{tg}$ mRNA levels in both liver and gonad confirmed that ERs signaling was involved in chlordecone-induced estrogenic responses (Kuiper et al., 1998). The observed induction of $v \operatorname{tg}$ mRNA in the gonad might be a localized response upon exposure to estrogenic chemicals. As indicated in the ER agonism AOP (Knapen et al., 2015), up-regulated vtg mRNA may result in VTG deposition in renal tissue, and this can be supported by the increased RSI and renal pathology in the present study. However, we observed decreased GSI in female rare minnow and further histopathological analysis revealed increased number of immature follicles and the appearance of atresia in ovaries of chlordecone exposed fish. Similar results have also been reported in catfish (Heteropneustes fossilis), and Atlantic croaker (Micropogonias undulatus) exposed chlordecone (Ghosh and Thomas, 1995; Srivastava and Srivastava, 1994) and in fathead minnow, zebrafish, medaka and rare minnow upon exposure to EE2 (Pawlowski et al., 2004; Seki et al., 2002; Van den Belt et al., 2001; Zha et al., 2007). Thus it is reasonable to speculate such effects as typical adverse effects in female fish which may result in adverse outcomes on reproduction such as reduction of egg production and mean fertility by estrogenic chemicals (Seki et al., 2002; Zha et al., 2006). One possible explaination for this is nongenomic estrogen action. For example, Fitzgerald et al. (2015) reported that BPA can maintain meiotic arrest and prevent maturation of oocyte through a G-protein coupled estrogen receptor/epidermal growth factor receptor pathway. Further studies would be required to elabrate the nongenomic mechanism underlying chlordecone-induced endocrine disruptions and establish corresponding AOPs for chemical risk assessment. Taken together, our results support an agonism of ERs by chlordecone in female rare minnow, and also indicated existence of other mechanism such as nongenomic estrogen action.

Besides, our molecular docking results also pointed to additional possible MIEs such as agonism of chlordecone with CYP19A and AR. The AR and dmrt1 were known to be required for male gonadal differentiation and maintenance (Ohtani et al., 2003; Matson et al., 2010). However, AR gene has also been found expressed in ovary, where its expression could be induced by testosterone (Weil et al., 1998). Dmrt1 mRNA is also found expressed in both testes and ovary (Guo et al., 2005; Lindeman et al., 2015), and its expression in the gonads appears to be downregulated in response to estrogen (Marchand et al., 2000) and upregulated in response to androgen (Shibata et al., 2002). Hence the up-regulation of ovarian ar and dmrt1 mRNA levels, together with the observed agonistic affinity of AR by chlordecone in the molecular docking results, may indicate possibility of androgenic agonistic mode of action. However, the in vitro results from the Pubchem database (NIH, 2016) showed that the disrupting potency with AR $(50.1 \mu \mathrm{M})$ could be weaker than with $\mathrm{ER} \alpha(3.38 \mu \mathrm{M})$, indicating that $\mathrm{ER} \alpha$ agonism may play more important role than AR agonism. The enzyme encoded by CYP19A were known to catalyze the conversion of T to E2 thus disturb the homeostasis of sex steroid hormones (Yaron and Levavi-Sivan, 2011). In the present study, mRNA levels of cyp19a were found up-regulated in the ovary of rare minnow after exposure to chlordecone. Accordingly, the ratio of E2/T were also increased, which means more $\mathrm{T}$ were transformed to E2. These results may support the molecular docking results which indicated an agonistic affinity of chlordecone with CYP19A. The binding energies indicated even higher interacting affinity of chlordecone with CYP19A than with the steroid receptors. According to Spano et al. (2004), the balance other than single concentration of the sex steroids was attributed to the final disrupting effects upon EDCs. These results may indicate an important role of CYP19A agonism in chlordecone-induced endocrine disruption.

Interestingly, we found similar inverted $U$ shaped dosedependent relationships in the changing profiles of ovarian er $\alpha$ and ar mRNA and plasma E2 and T levels of female rare minnow upon chlordecone exposure. Therefore it also seems reasonable that the changes of mRNA for er $\alpha$ and ar were due to the increase of endogenous sex hormones. Inverted " $U$ " shaped dose-dependent relationships in er $\alpha$ and $v \operatorname{tg}$ mRNA response have been reported in liver from kryptolebias marmoratus exposed to E2 (Park et al., 2009) and estuarine killifish (fundulus heteroclitus) exposed to ethinylestradiol (Hogan et al., 2010). Similar changing profiles have also been reported previously for plasma E2 levels in zebrafish after exposure to fluorotelomer alcohols (Liu et al., 2009) and for serum T levels in female crucian carp after exposure to pentachlorophenol (Zhang et al., 2008). The endogenous sex hormone levels are closely related to their synthesis in target tissues, predominantly the gonads in fish. The synthesis rates are controlled by enzymes such as CYP11A1 and CYP17 which play critical role in synthesis of T from cholesterol, and CYP19 which catalyzes the conversion of T to E2 (Yaron and Levavi-Sivan, 2011). In the present study, the transcripts of ovarian cyp11a1 and cyp17 were significantly increased, which may suggest a promotion of steroid synthesis and explain the elevated circulating E2 and T. In turn, the expression and activities of the enzymes involved in steroid synthesis are mainly controlled by hypothalamic gonadotropin-releasing hormones (GnRHs) via pituitary-derived gonadotropic hormones (GtHs) including folliclestimulating hormone (FSH) and luteinizing hormone (LH) in fish (Nagahama et al., 1994; Yaron et al., 2003). Therefore, it seems reasonable that the induced transcription of ovarian cyp11a1 and cyp17, and even cyp19a, were attributed to the up-regulated brain gnrh3 mRNA levels, which also showed inverted U shaped profile. Thus the induction of gnrh3 transcription and upregulated transcription of ovarian cyps and steroid receptors as well as plasma hormone levels could be viewed as part of a feed-forward response to chlordecone exposure in female rare minnow. However, the MIE responsible for the gnrh3 induction would be still unclear, because a repression of gnrh were usually caused by E2 through ERs (Dong et al., 1996; Chen et al., 2000) and agonism of AR also resulted in decreased secretion of GtH (Knapen et al., 2015).

Hence, the mechanism(s) of endocrine disruption in female rare minnow upon chlordecone exposure could be summarized in Fig. 5 
based on the network of known adverse outcome pathways (Knapen et al., 2015) with modifications. The figure indicated important roles of agonism of estrogen receptors and CYP19A and existence of agonism of androgen receptor, also suggests possibility of other potential MIEs. These interactions may evoke a feedforward response of the HPG axis to chlordecone exposure in female rare minnow.

In the case of male rare minnow, significantly induction were observed for gonad transcripts of $\operatorname{er} \alpha$, but not for those of $\operatorname{er} \beta$ and $a r$. The in vitro results from the Pubchem database (NIH, 2016) also showed that chlordecone exhibited stronger agonistic potency with $\mathrm{ER} \alpha(3.38 \mu \mathrm{M})$ than with $\mathrm{AR}(50.1 \mu \mathrm{M})$. In contrast, hepatic er $\alpha$ mRNA levels were significantly downregulated in male fish exposed to chlordecone at $0.1 \mu \mathrm{g} \mathrm{L}^{-1}$ and higher. Previous studies in rats also indicated that the interaction of chlordecone with estrogen receptor system appears to be tissue-dependent (Williams et al., 1989). Although chlordecone showed no docking affinity with antagonistic ER $\alpha$ in the present study, in vitro results from the Pubchem database $(\mathrm{NIH}, 2016)$ showed that it could inhibit the ER $\alpha$ signaling, and the inhibiting potency $(7.9 \mu \mathrm{M})$ was approximate equal with the promoting potency $(3.38 \mu \mathrm{M})$. One possible explaination was the ratio of coactivators to corepressors of ER $\alpha$ may showed different changing trends in liver and gonad of rare minnow upon chlordecone, which may determine whether this exogenous ligand behaves primarily as an agonist or antagonist (Li et al., 2007). The down-regulated mRNA of hepatic $\operatorname{er} \alpha$ and $\operatorname{er} \beta$ may also indicated a negative feedback, thus may explain the lack of upregulation of hepatic vtg mRNA. Elevated mRNA levels of er $\alpha$ and induction of VTG have been reported in fish, suggesting ER $\alpha$ as the major mediator of VTG production (Marlatt et al., 2008), which was consistent with the observations in gonad of male rare minnow. The upregulation of $v \operatorname{tg}$ mRNA in testis instead of that in liver of male fish confirmed the presumption that the induction of gonadal $v t g$ mRNA may be localized response upon exposure to estrogenic chemicals, and may be related to the histopathological observations in male rare minnow. Although the GSI were not significantly changed, occurrence of abundant PO and EVO in the testis were found after long term exposure to chlordecone. Similar phenomenon such as intersex and testis-ova have been reported following EE2 exposure in medaka, zebrafish and fathead minnow (Lange et al., 2001; Nash et al., 2004; Metcalfe et al., 2001) and following NP exposure in medaka (Gray and Metcalfe, 1997). The intermediate condition of intersex was considered as typical consequence of transformation from testis to ovaries during early gonadal development under the direct influence of environmental estrogens (Lange et al., 2001; Nash et al., 2004). Above all, these results showed that chlordecone exhibited ER $\alpha$ agonistic potency in gonad and maybe ER $\alpha$ antagonistic potency in liver of male rare minnow upon long term exposure.

The increased ratio of E2/T provided evidence for an agonism of CYP19A by chlordecone as observed in the molecular docking results. The homeostasis of sex steroids was considered contribute to the final disrupting effects by EDCs (Spanò et al., 2004) and its disturbance may activate an auto-regulation of endocrine system leading toward increased transcription of steroidogenic enzymes involved in androgen synthesis (i.e. cyp11a and cyp17), along with decreased transcription of enzymes involved in E2 synthesis (i.e. cyp19a). The up-regulated transcription of cyp11a and cyp17 resulted in promotion of steroidogenesis which may explain the elevation of circulating E2 and T in the present study. In turn, these fluctuation triggered the negative feedback within the HPG axis, leading to significantly down-regulation of brain gnrh3 and cyp19b mRNA. Alternatively, the down-regulated brain gnrh3 could also be attributed to the agonistic interaction with AR by chlordecone as indicated by molecular docking results. Androgen receptor (AR)mediated down-regulation of GnRH mRNA levels have been reported (Brayman et al., 2012), and a related AOP showed that androgen receptor agonism resulted in Reduced GtRH (Knapen et al., 2015), which were mainly regulated by GnRH. Despite a lack of increase in testis ar mRNA levels, dmrt1 mRNA were induced

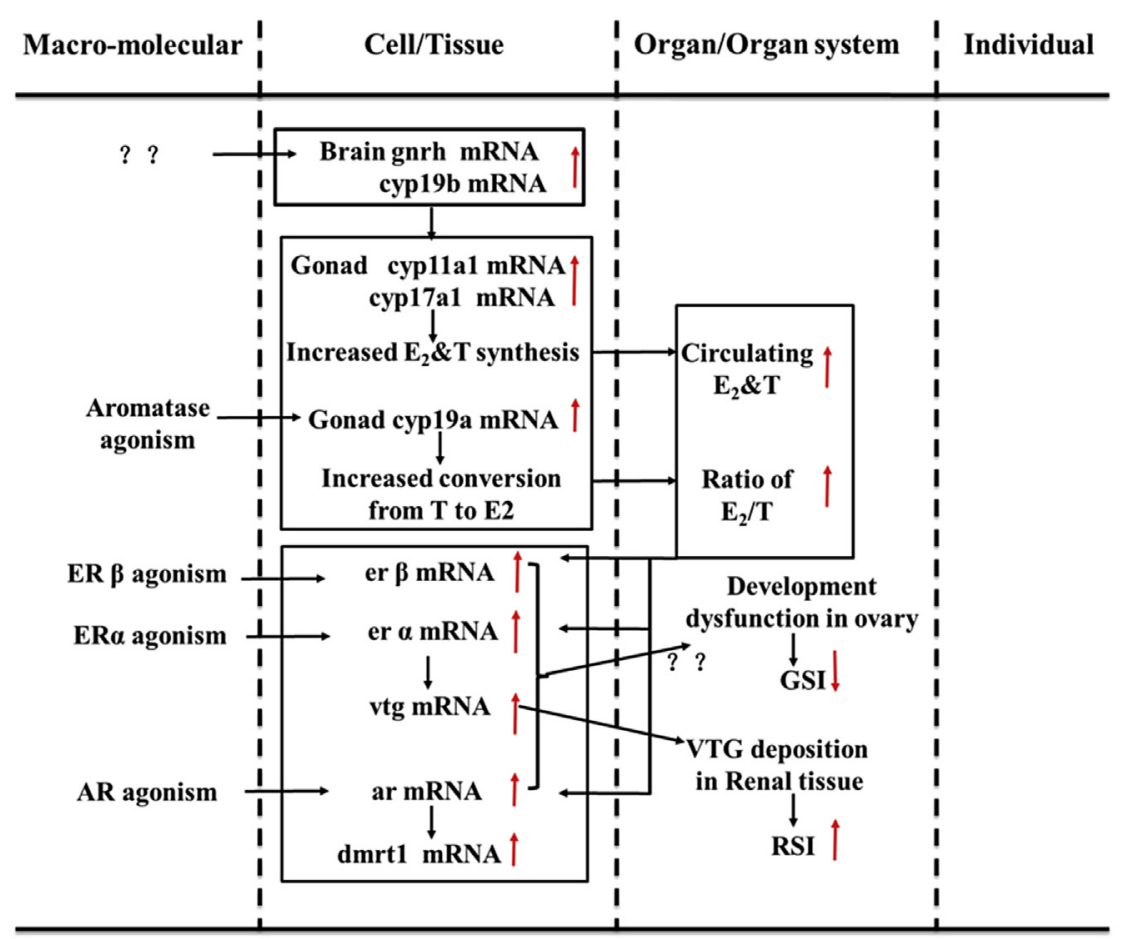

Fig. 5. A diagram of chlordecone-induced endocrine disruption in female rare minnow (Gobiocypris rarus) based on the adverse outcome pathway framework. 


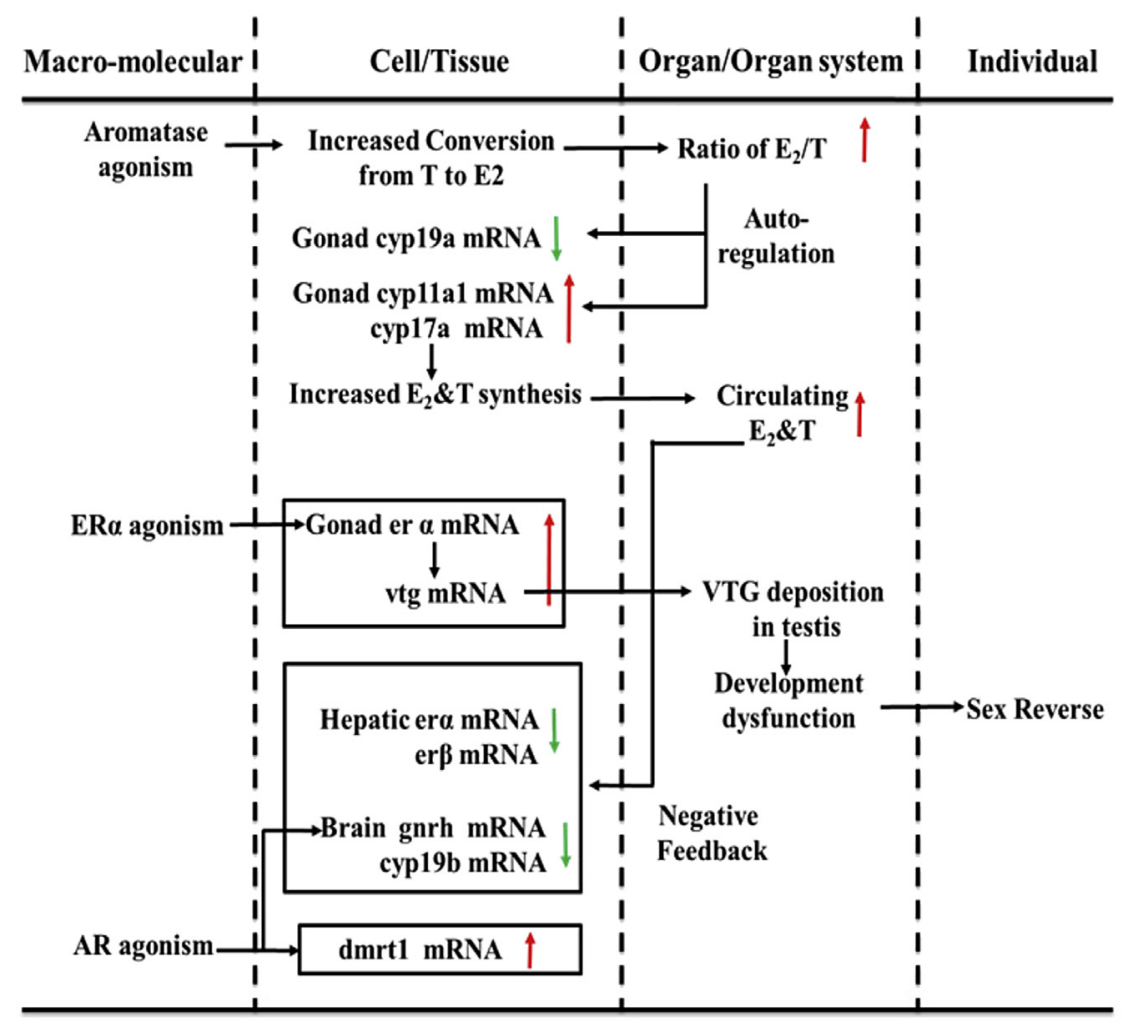

Fig. 6. A diagram of chlordecone-induced endocrine disruption in male rare minnow (Gobiocypris rarus) based on the adverse outcome pathway framework.

to some extent in the present study. Anyway, these results may indicate a possibility of AR agonism by chlordecone in male rare minnow.

Hence, the mechanism(s) of endocrine disruption in male rare minnow upon chlordecone exposure could be summarized in Fig. 6. The figure presented agonism of ER $\alpha$ and CYP19A by chlordecone, accompanied by agonism of androgen receptor and maybe antagonism of ERs. These interactions may evoke a negative feedback of the HPG axis to chlordecone exposure in male rare minnow.

\section{Conclusions}

In conclusions, our results provide in silico and in vivo evidence for agonism of ERs and CYP19A in chlordecone-induced endocrine disruptions, and also indicated possibilities of other MIEs such as agonism of AR, antagonism of ERs, as well as nongenomic events. However, the results could not sufficiently explained based on the already described AOPs at present. Further studies aiming to elabrate toxicological mechanism and establish corresponding AOPs would be necessary for expanding AOP network and implementing its use in chemical risk assessment.

\section{Acknowledgements}

This work was supported by the National Natural Science Foundation of China (21307153, 21407166), and Beijing Natural Science Foundation (8152017).

\section{Appendix A. Supplementary data}

Supplementary data related to this article can be found at http:// dx.doi.org/10.1016/j.chemosphere.2016.07.034.

\section{References}

Ankley, G.T., Bennett, R.S., Erickson, R.J., Hoff, D.J., Hornung, M.W., Johnson, R.D. Mount, D.R., Nichols, J.W., Russom, C.L., Schmieder, P.K., Serrrano, J.A., Tietge, J.E., Villeneuve, D.L., 2010. Adverse outcome pathways: a conceptual framework to support ecotoxicology research and risk assessment. Environ. Toxicol. Chem. 29, 730-741.

Balthazart, J., Baillien, M., Ball, G.F. 2001. Phosphorylation processes mediate rapid changes of brain aromatase activity. J. Steroid Biochem. Mol. Biol. 79, 261-277.

Bjornstrom, L., Sjoberg, M., 2005. Mechanisms of estrogen receptor signaling: convergence of genomic and nongenomic actions on target genes. Mol. Endocrinol. 19, 833-842.

Boucher, O., Simard, M.N., Muckle, G., Rouget, F., Kadhel, P., Bataille, H., Chajes, V. Dallaire, R., Monfort, C., Thome, J.P., Multigner, L., Cordier, S., 2013. Exposure to an organochlorine pesticide (chlordecone) and development of 18-month-old infants. Neurotoxicology 35, 162-168.

Brayman, M.J., Pepa, P.A., Berdy, S.E., Mellon, P.L., 2012. Androgen receptor repression of gnrh gene transcription. Mol. Endocrinol. 26, 2-13.

Chen, Z.G., Yu, K.L., Zheng, H.M., Dong, K.W., 2000. Estrogen receptor-mediated repression of gonadotropin-releasing hormone (gnrh) promoter activity in transfected cho-k1 cells. Mol. Cell. Endocrinol. 158, 131-142.

Dong, K.W., Chen, Z.G., Cheng, K.W., Yu, K.L., 1996. Evidence for estrogen receptormediated regulation of human gonadotropin-releasing hormone promoter activity in human placental cells. Mol. Cell. Endocrinol. 117, 241-246.

Faroon, O., Kueberuwa, S., Smith, L., DeRosa, C., 1995. ATSDR evaluation of health effects of chemicals. II. Mirex and chlordecone: health effects, toxicokinetics, human exposure, and environmental fate. Toxicol. Ind. Health 11, 1-195.

Fester, L., Brandt, N., Windhorst, S., Prols, F., Blaute, C., Rune, G.M., 2015. Control of aromatase in hippocampal neurons. J. Steroid Biochem. Mol. Biol. 160, 9-14.

Fitzgerald, A.C., Peyton, C., Dong, J., Thomas, P., 2015. Bisphenol A and related alkylphenols exert nongenomic estrogenic actions through a $G$ protein-coupled estrogen receptor 1 (gper)/epidermal growth factor receptor (egfr) pathway to inhibit meiotic maturation of zebrafish oocytes. Biol. Reprod. 93, 135.

Ghosh, S., Thomas, P., 1995. Antagonistic effects of xenobiotics on steroid induced final maturation of Atlantic croaker oocytes in vitro. Mar. Environ. Res. 39 159-163.

Gray, M.A., Metcalfe, C.D., 1997. Induction of testis-ova in Japanese medaka (Oryzias latipes) exposed to p-nonylphenol. Environ. Toxicol. Chem. 16, 1082-1086.

Groh, K.J., Carvalho, R.N., Chipman, J.K., Denslow, N.D., Halder, M., Murphy, C.A Roelofs, D., Rolaki, A., Schirmer, K., Watanabe, K.H., 2015. Development and application of the adverse outcome pathway framework for understanding and predicting chronic toxicity: i. challenges and research needs in ecotoxicology. Chemosphere 120, 764-777. 
Guldner, L., Multigner, L., Héraud, F., Monfort, C., Thomé, J.P., Giusti, A., Kadhel, P., Cordier, S., 2010. Pesticide exposure of pregnant women in Guadeloupe: ability of a food frequency questionnaire to estimate blood concentration. Environ. Res. 110, 146-151.

Guo, Y., Cheng, H., Huang, X., Gao, S., Yu, H., Zhou, R., 2005. Gene structure, multiple alternative splicing, and expression in gonads of zebrafish dmrt1. Biochem. Biophys. Res. Commun. 330, 950-957.

Hogan, N.S., Currie, S., Leblanc, S., Hewitt, L.M., Maclatchy, D.L., 2010. Modulation of steroidogenesis and estrogen signalling in the estuarine killifish (fundulus heteroclitus) exposed to ethinylestradiol. Aquat. Toxicol. 98, 148-156.

IARC, 1979. Chlordecone. IARC Monographs on the Evaluation of Carcinogenic Risk of Chemicals to Humans: Some Halogenated Hydrocarbons. Lyon, France.

Knapen, D., Vergauwen, L., Villeneuve, D.L., Ankley, G.T., 2015. The potential of AOP networks for reproductive and developmental toxicity assay development. Reprod. Toxicol. 56, 52-55.

Kuiper, G.G.J.M., Lemmen, J.G., Carlsson, B., Corton, J.C., Safe, S.H., van der Saag, P.T., van der Burg, B., Gustafsson, J., 1998. Interaction of estrogenic chemicals and phytoestrogens with estrogen receptor beta. Endocrinology 139, 4252-4263.

Kurosawa, T., Hiroi, H., Tsutsumi, O., Ishikawa, T., Osuga, Y., Fujiwara, T., Inoue, S. Muramatsu, M., Momoeda, M., Taketani, Y., 2002. The activity of bisphenol A depends on both the estrogen receptor subtype and the cell type. Endocr. J. 49, 465-471.

Lange, R., Hutchinson, T.H., Croudace, C.P., Siegmund, F., Schweinfurth, H., Hampe, P., Panter, G.H., Sumpter, J.P., 2001. Effects of the synthetic estrogen $17 \alpha-$ ethinylestradiol on the life-cycle of the fathead minnow (Pimephales promelas). Environ. Toxicol. Chem. 20, 1216-1227.

Li, L., Andersen, M.E., Heber, S., Zhang, Q., 2007. Non-monotonic dose-response relationship in steroid hormone receptor-mediated gene expression. J. Mol. Endocrinol. 38, 569-585.

Lindeman, R., Gearhart, M., Minkina, A., Krentz, A., Bardwell, V., Zarkower, D., 2015. Sexual cell-fate reprogramming in the ovary by dmrt1. Curr. Biol. 25, 764-771.

Liu, C.S., Yu, L.Q., Deng, J., Lam, P.K., Wu, R.S.S., Zhou, B.S., 2009. Waterborne exposure to fluorotelomer alcohol 6: 2 FTOH alters plasma sex hormone and gene transcription in the hypothalamic-pituitary-gonadal (HPG) axis of zebrafish. Aquat. Toxicol. 93, 131-137.

Luellen, D.R., Vadas, G.G., Unger, M.A., 2006. Kepone in James river fish: 1976-2002. Sci. Total Environ. 358, 286-297.

Marchand, O., Govoroun, M., D'Cotta, H., McMeel, O., Lareyne, J., Bernot, A Laudet, V., Guiguen, Y., 2000. DMRT1 expression during gonadal differentiation and spermatogenesis in the rainbow trout, Oncorhynchus mykiss. Biochim. Biophys. Acta 1493, 180-187.

Marlatt, V.L., Martyniuk, C.J., Zhang, D., Xiong, H., Watt, J., Xia, X., Moon, T., Trudeau, V.L., 2008. Auto-regulation of estrogen receptor subtypes and gene expression profiling of 17 beta-estradiol action in the neuroendocrine axis of male goldfish. Mol. Cell Endocrinol. 283, 38-48.

Matson, C.K., Murphy, M.W., Griswold, M.D., Yoshida, S., Bardwell, V.J., Zarkower, D., 2010. The mammalian doublesex homolog dmrt1 is a transcriptional gatekeeper that controls the mitosisversus meiosis decision in male germ cells. Dev. Cell 19, 612-624.

Metcalfe, C.D., Metcalfe, T.R., Kiparissis, Y., Koening, B.G., Khan, C., Hughes, R.J. Croley, T.R., March, R.E., Potter, T., 2001. Estrogenic potency of chemicals detected in sewage treatment plant effluents as determined by in vivo assays with Japanese medaka (Oryzias latipes). Environ. Toxicol. Chem. 20, 297-308.

Nagahama, Y., Yoshikuni, M., Yamashita, M., Tokumoto, T., Katsu, Y., 1994. Egulation of oocyte growth and maturation in fish. In: Nilsen-Hamilton, M. (Ed.), Current Topics in Developmental Biology, vol. 30. Academic Press Inc., New York, pp. 103-146.

Nash, J.P., Kime, D.E., Van der Ven, L.T.M., Wester, P.W., Brion, F., Maack, G. Stahlschmidt-Allner, P., Tyler, C.R., 2004. Long-term exposure to environmental concentrations of the pharmaceutical ethynylestradiol causes reproductive failure in fish. Environ. Health. Perspect. 112, 1725-1733.

U.S. National Institutes of Health $(\mathrm{NIH}), 2016$. Database of Pubchem Bioassay (accessed 16.03.03). https://pubchem.ncbi.nlm.nih.gov/assay/bioactivity.html? cid $=299$.

NLM, 2004. Chlordecone. HSDB (Hazardous Substances Data Bank). National Institutes of Health, U.S. Department of Health and Human Services, Bethesda, Maryland.

Ohtani, H., Miura, I., Ichikawa, Y., 2003. Role of aromatase and androgen receptor expression in gonadal sex differentiation of zw/zz-type frogs, rana rugosa. Comp. Biochem. Phys. C 134, 215-225.
Park, C.B., Aoki, J.Y., Lee, J.S., Nagae, M., Lee, Y.D., Sakakura, Y., Hagiwarab, A., Soyanoa, K., 2009. The effects of $17 \beta$-estradiol on various reproductive parameters in the hermaphrodite fish kryptolebias marmoratus. Aquat. Toxicol. 96, 273-279.

Pawlowski, S., van Aerle, R., Tyler, C.R., Braunbeck, T., 2004. Effects of $17 \alpha$ - ethinylestradiol in a fathead minnow (Pimephales promelas) gonadal recrudescence assay. Ecotoxicol. Environ. Saf. 57, 330-345.

Scippo, M.L., Argiris, C., Van De Weerdt, C., Muller, M., Willemsen, P., Martial, J., Maghuin-Rogister, G., 2004. Recombinant human estrogen, androgen and progesterone receptors for detection of potential endocrine disruptors. Anal. Bioanal. Chem. 378, 664-669.

Seki, M., Yokota, H., Matsubara, H., Tsuruda, Y., Maeda, M., Tadokoro, H., Kobayashi, K., 2002. Effect of ethinylestradiol on the reproduction and induction of vitellogenin and testis-ova in medaka (Oryzias latipes). Environ. Toxicol. Chem. 21, 1692-1698.

Shibata, K., Takase, M., Nakamura, M., 2002. The Dmrt1 expression in sex-reversed gonads of amphibians. Gen. Comp. Endocrinol. 127, 232-241.

Spanò, L., Tyler, C.R., van Aerle, R., Devos, P., Mandiki, S.N.M., Silvestre, F., Thoméc, J., Kestemont, P., 2004. Effects of atrazine on sex steroid dynamics, plasma vitellogenin concentration and gonad development in adult goldfish (Carassius auratus). Aquat. Toxicol. 66, 369-379.

Srivastava, A.K., Srivastava, A.K., 1994. Effect of chlordecone on gonads of freshwater catfish, Heteropneustes fossilis. Bull. Environ. Contam. Toxicol. 53, 186-191.

U.N.E.P., 2007. Report of the persistent Organic Pollutants Review Committee on the work of its third meeting. Revised risk profile on chlordecone. In: Third Meeting of the Persistent Organic Pollutants Review Committee (POPRC-3). UNEP/POPS/ POPRC, Geneva, Switzerland.

U.S. EPA, 1986. Final Report on the Evaluation of Four Toxic Chemicals in an in Vivo/ in Vitro Toxicological Screen: Acrylamide, Chlordecone, Cyclophosphamide, and Diethylstilbestrol. Washington D.C., USA.

Van den Belt, K., Verheyen, R., Witters, H., 2001. Reproductive effects of ethynylestradiol and 4-t-octylphenol on the zebrafish (Danio rerio). Arch. Environ. Contam. Toxicol. 41, 458-467.

Wang, J., 1992. Reproductive biology of Gobiocypris rarus. Acta Hydrobio. Sin. 16, 165-175 (In Chinese).

Wang, H., Tan, J.T.T., Emelyanov, A., Korzh, V., Gong, Z., 2005. Hepatic and extrahepatic expression of vitellogenin genes in the zebrafish, Danio rerio. Gene 356, 91-100.

Weil, S.J., Vendola, K., Zhou, J., Adesanya, O.O., Wang, J., Okafor, J., Bondy, C.A., 1998. Androgen receptor gene expression in the primate ovary: cellular localization, regulation, and functional correlations. J. Clin. Endocr. Metab. 83, 2479-2485.

Williams, J., Eckols, K., Uphouse, L., 1989. Estradiol and chlordecone interactions with the estradiol receptor. Toxicol. Appl. Pharmacol. 98, 413-421.

Wolf, J.C., Dietrich, D.R., Friederich, U., Caunter, J., Brown, A.R., 2004. Qualitative and quantitative histomorphologic assessment of fathead minnow (Pimephales promelas) gonads as an endpoint for evaluating endocrine-active compounds: a pilot methodology study. Toxicol. Pathol. 32, 600-612.

Yang, L., Zha, J., Wei, L., Li, Z., Wang, Z., 2010. Atrazine affects kidney and adrenal hormones (AHs) related genes expressions of rare minnow (Gobiocypris rarus). Aquat. Toxicol. 97, 204-211.

Yang, L., Zha, J., Wei, L., Li, Z., Wang, Z., 2011. Vinclozolin affects the interrenal system of the rare minnow (Gobiocypris rarus). Aquat. Toxicol. 104, 153-159.

Yaron, Z., Gur, G., Relamed, P., Rosenfeld, H., Elizur, H., Levavi-Sivan, B., 2003. Regulation of fish gonadotropins. In: Kwang, W.J. (Ed.), International Review of Cytology-A Survey of Cell Biology, vol. 225. Academic Press Inc, San Diego, pp. 131-185.

Yaron, Z., Levavi-Sivan, B., 2011. Endocrine regulation of fish reproduction. In: Farrell, A.P. (Ed.), Encyclopedia of Fish Physiology: from Genome to Environment, vol. 2. Academic Press Inc., Oxford, pp. 1500-1509.

Zha, J., Wang, Z., Schlenk, D., 2006. Effects of pentachlorophenol on the reproduction of Japanese medaka (Oryzias latipes). Chem-Biol. Interact. 161, 26-36.

Zha, J., Wang, Z., Wang, N., Ingersoll, C., 2007. Histological alternation and vitellogenin induction in adult rare minnow (Gobiocypris rarus) after exposure to ethynylestradiol and nonylphenol. Chemosphere 66, 488-495.

Zhang, M., Yin, D., Kong, F., 2008. The changes of serum testosterone level and hepatic microsome enzyme activity of crucian carp (Carassius carassius) exposed to a sublethal dosage of pentachlorophenol. Ecotoxicol. Environ. Saf. 71, 384-389.

Zhou, B.S., 2015. Adverse outcome pathway: framework, application, and challenges in chemical risk assessment. J. Environ. Sci. 35, 191-193. 